
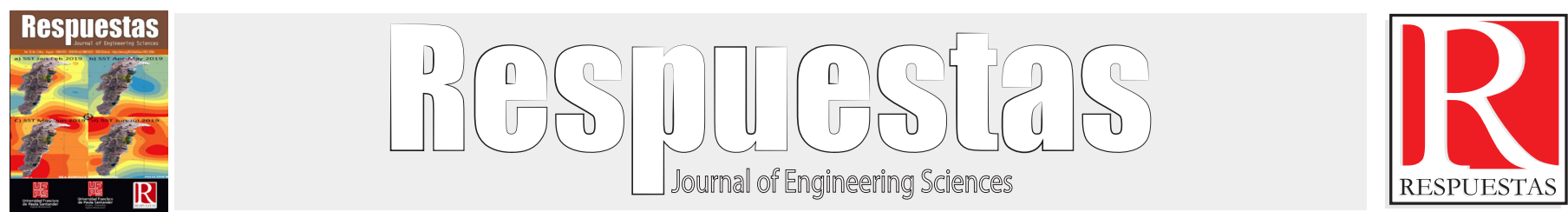

Original Article

https://doi.org/10.22463/0122820X.2964

\title{
Review: Densification process of ceramic materials
}

Revisión: Métodos de densificación de materiales cerámicos

Isabel Cristina Minota-Yepes ${ }^{1}$, Román Álvarez-Roca ${ }^{2}$, Fernando Andrés Londoño-Badillo ${ }^{3}$

'Grupo de Estado Sólido, Facultad de Ciencias Exactas y Naturales, isabel.minota@udea.edu.co, Universidad de Antioquia, Medellin, Colombia. ${ }^{2}$ CDMI/LIEC, Chemistry Dpto, cortes116@yahoo.es, Universidade Federal de São Carlos, São Carlos, Brasil.

${ }^{3}$ Grupo de Instrumentación Cientifica y Microelectrónica, Facultad de Ciencias Exactas y Naturales, fernandoa.londono@udea.edu.co, Universidad de Antioquia, Medellin, Colombia.

How to cite: I.C. Minota-Yepes, R. Álvarez-Roca, F.A. Londoño-Badillo, “Review: Densification process of ceramic materials”. Respuestas, vol. 25, no. 2, pp. 199-212, 2020.

Received on June 30, 2019; Approved on November 10, 2019

\begin{tabular}{ll}
\hline & ABSTRACT \\
\hline Keywords: & Ceramics have played a very important role in the technological and socioeconomic development of mankind, \\
& to such an extent that they can be used to identify different historical periods of humanity. Babylonians, Greeks, \\
Conventional; & Andalusians, among other cultures have used ceramics and developed various methods to improve the products \\
obtained from pottery. In general, ceramics can be divided into two main areas, traditional ceramics and structural \\
ceramics. Ceramics made from clays, Traditional Ceramics, are currently being studied in the improvement of \\
Hot Pressing;
\end{tabular}$\quad \begin{aligned} & \text { structural materials, abrasives, cements, refractories, among others. On the other hand, ceramics developed as a } \\
& \text { consequence of new technologies and the exploitation of natural resources, Structural Ceramics, are of great interest } \\
& \text { for the science of ceramic materials due to the development of ceramics with properties that manage to incorporate } \\
& \text { attributes of diverse materials in a single material, in addition to contributing to the phenomenological study at } \\
& \text { a scientific level. Advances in the densification and doping processes of these materials have allowed obtaining } \\
& \text { ceramics with high mechanical strength, high hardness, high resistance to wear and corrosion, good chemical and } \\
& \text { thermal stability; characteristics that have directly influenced the type of applications such as: bulletproof vests, } \\
& \text { transparent shielding, high temperature electrical insulators, superconducting devices, electronic materials, among } \\
& \text { other applications. In order to achieve optimum properties, the microstructure of the material is manipulated by } \\
& \text { means of densification parameters which characterize each of the methods, conventional densification, densification } \\
& \text { by plasma pulses and densification by hot pressing. This work aims to establish a relationship between the different } \\
& \text { methods and their influence on ceramic materials, highlighting similarities, efficiency, validity, their possible and } \\
& \text { future applications, advantages and disadvantages of each method. }\end{aligned}$

\section{RESUMEN}

\section{Palabras clave:}

Análisis bibliométrico, Cemento,

Sustitutos,

Tendencias de

Investigación.
Las cerámicas han tenido un papel muy importante en el desarrollo tecnológico y socioeconómico de la humanidad, a tal punto que pueden ser utilizadas para identificar diferentes periodos históricos de la humanidad. Babilonios, griegos, andaluces, entre otras culturas han utilizado la cerámica y desarrollado diversos métodos para mejorar los productos obtenidos a partir de la alfarería. En general, las cerámicas pueden ser divididas en dos grandes áreas, cerámicas tradicionales y cerámicas estructurales. Las cerámicas fabricadas con arcillas, Cerámicas Tradicionales, actualmente son estudiadas en el mejoramiento de materiales estructurales, abrasivos, cementos, refractarios, entre otros. Por otro lado, las cerámicas desarrolladas como consecuencia de las nuevas tecnologías y la explotación de recursos naturales, Cerámicas Estructurales, son de gran interés para la ciencia de los materiales cerámicos debido al desarrollo de cerámicas con propiedades que logran incorporar atributos de diversos materiales en un único material, además de contribuir con el estudio fenomenológico a nivel científico. Avances en los procesos de densificación y dopaje de estos materiales han permitido obtener cerámicas con alta resistencia mecánica, alta dureza, elevada resistencia al desgaste y a la corrosión, buena estabilidad química y térmica; características que han influido directamente en el tipo de aplicaciones como: chalecos antibalas, blindajes transparentes, aislantes eléctricos de alta temperatura, dispositivos superconductores, materiales electrónicos entre otras aplicaciones. Para que las propiedades sean óptimas se manipula la microestructura del material por medio de los parámetros de densificación los cuales caracterizan cada uno de los métodos, densificación convencional, densificación por impulsos de plasma y densificación por prensado en caliente. Este trabajo pretende establecer una relación entre los diferentes métodos y la influencia de estos en los materiales cerámicos, resaltando semejanzas, eficiencia, vigencia, sus posibles y futuras aplicaciones, ventajas y desventajas de cada método. 


\section{Introducción}

Throughout history, technology has facilitated the development of mankind, marking a focus of change in human behavior that, in turn, has enabled new technological innovations. Materials technology has also had a great impact on the evolution of civilizations; historians have defined several periods in human history as the stone age, the bronze age, the iron age and the age of synthetic materials. Each period followed by another and triggered by the invention of better products, the beginning of the 21st century has witnessed the emergence of smart materials, this has been categorized by a revolutionary technology that exploits several emerging technologies such as: materials science, biotechnology, biomedicine, nanotechnology, molecular electronics and artificial intelligence among other cutting edge technologies in various fields of science that have been developed by engineers, chemists, physicists and materials scientists to synthesize, analyze and produce a new generation of materials.

The development of ceramic materials throughout history has been very important for technological advances, such as the creation of varistors, insulators, sensors, among others. There is a direct relationship between the progress in obtaining these devices with the densification processes, as well as with the progress in ceramic materials. For example, PZT ceramics currently used for piezoelectric applications are intended to be replaced by lead-free KNN ceramics, which reduces the impact on human health. However, to achieve the characteristics of lead-based compounds, it has been necessary to improve the methods for obtaining KNN, such as the use of hotpress densification and plasma pulse densification. In general, the advances in the field of materials science are highly influenced by the densification methods, since it is essential to change the microstructure of the materials and this requires a study and a transformation in the parameters present in the densification [1], [2], [3], [4], [5], [6].

The fabrication of most ceramic formings begins with the preparation of the powder. These are pressed to the required shapes and sizes, and densified to obtain mechanically strong and dense ceramics, the most important processes influencing the final ceramic characteristics and properties being: powder preparation, calcination and densification. [7].
Some of the processing conditions may include doping and atmosphere control. For example, doping with erbium in transparent PLZT ceramics results in increased mechanical strength, thermal strength and chemical stability, as well as decreased manufacturing cost [8]. Other studies relate grain growth to simultaneous doping as in the case of ceramics doped with lanthanum and niobium [9].

Studies have also been carried out on densification by hot pressing assisted with oxygen atmosphere control, obtaining transparent ferro-electric ceramics that are used in the electro-optical industry [10], [4]. The technique of densification by hot pressing with the aid of oxygen created at the experimental level was so beneficial for obtaining materials with optical and electro-optical qualities that it has been assimilated by the industry, for example, the Boston Applied Technologies, Inc, Bati, manufactures modulators and optical switches with ceramics of the PMN-PT: La system obtained by hot pressing [11], [12], [13], [14].

In general the densification process can be considered the most important step when looking for suitable characteristics for a certain application, parameters such as time, atmosphere, densification temperature and heating and cooling rate, are responsible for obtaining one or another crystalline structure, grain size and porosity, which in the end accounts for the characteristics of the ceramic material [15].

The relationships between chemical composition, atomic structure, fabrication, microstructure and properties of polycrystalline ceramics are illustrated in Figure 1. The intrinsic properties should be considered at the time of material selection, while the final properties can be maximized during the calcination and densification processes. The role of the fabrication process, then, is to produce microstructures with the desired engineering properties. For example, the measured dielectric constant of the fabricated $\mathrm{BaTiO} 3$ will depend significantly on the microstructure (grain size, porosity and presence of any secondary phases). Typically, the overall fabrication method can be broken down into a few or several discrete steps, depending on the complexity of the method. Although there is no generally accepted terminology, these discrete steps are known as processing steps. Within the processing, this review will emphasize some of the commonly used methods for densification 
of ceramics (conventional densification, hot pressing and plasma pulses), orienting the study to the influence of densification processes on mechanical, electrical, magnetic, optical properties, among others, and to the possible applications, past, present and future, depending on the densification processes of ceramic materials [15].

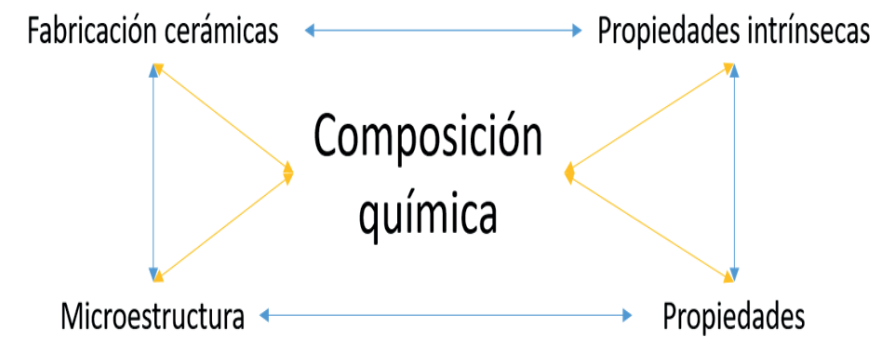

Figure 1. Diagram of relationship between the different properties of ceramic materials. Source: Own

\section{History of densification processes}

The densification of ceramic materials dates back to $10,000 \mathrm{BC}$ with the potters and the creation of their utensils, for domestic and artistic use, which were shaped with clays and dried in the sun [16]. Around $575 \mathrm{BC}$ it was the Babylonians who innovated with new vitrified resins, the Greeks proposed an improved heating process that consisted of pre-firing the pots to mark them while they were still wet and then putting them in the kiln to dry to obtain better hardness and impermeability [17]. The appearance of pottery, the advances and improvements in the densification process influenced domestic, cultural, artistic and commercial use, for example, the Andalusians (in the year of the Andalusians) used ceramics to embellish their streets as a new pavement, replacing marble. With respect to the manufacture of this type of ceramics, known as "traditional ceramics", three steps can be highlighted in the process of obtaining them: first, the selection and mixing of powders; second, shaping; and third, densification. Each of these steps has been improved over time, and the densification methods and their relationship with the final properties of the material have also been extensively studied in electroelectronic ceramics [21], [22], [23], [24].

The importance of densification methods in ceramic materials has its beginnings from the use of firewood as a fuel source to obtain bricks [17]. In order to make more efficient use of the energy produced by firewood, the Muslims created the so-called "Moorish kiln" (Figure 2), which allowed higher temperatures to be reached than their predecessors. Higher densification temperatures were only possible many years later with the appearance of muffle furnaces [17], later with the advent of electricity, it was possible to reach densification temperatures of so many degrees, however, the need for new materials prompted the development of densification systems such as: conventional densification with atmosphere control, hot pressing, microwave densification, plasma impulse, among others [16].

The development of densification processes has also been very significant in the electro-electronic ceramics industry [25]-[28]. Improvements in densification processes have allowed the optimization of materials such as PZT, where the doping process (lanthanum) and improvements in densification processes (hot pressing) have allowed obtaining materials with various properties (ferro-electric, electro-optical and magnetic) [26].

Densification by hot pressing aided by oxygen atmosphere control, implemented in 1973, allowed obtaining ferroelectric ceramics with higher transparency than those obtained in 1969 [10], [29].

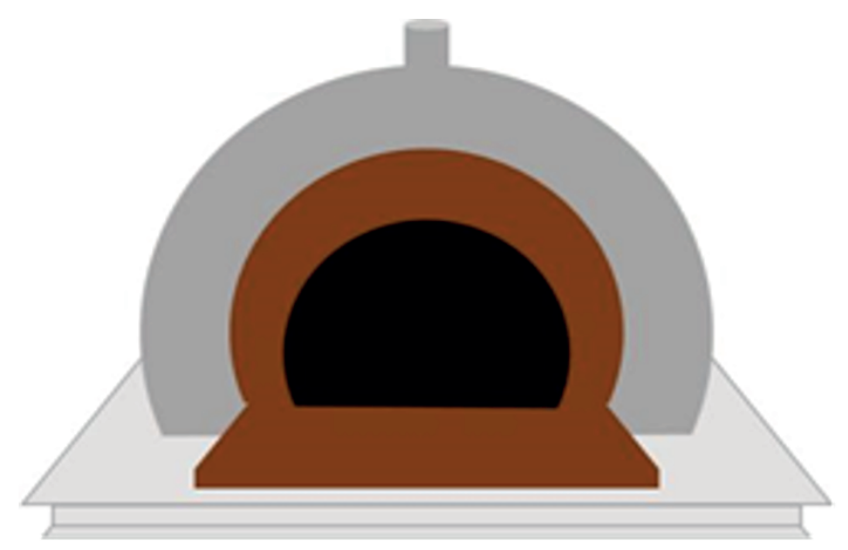

Figure 2. Morunos kiln of the first kilns used for the densification of ceramics. Source: Own

In South America, advanced densification processes have been used since the 1990s with the work of García, Kiminami, Londoño and others [6], [8], [30], [31]. Currently, densification techniques such as pulsed plasma and microwave densification have contributed to improve and obtain properties in ceramics such as SBT type ceramics. The conventionally densified $\mathrm{Sr} 0.5 \mathrm{Ba} 0.5 \mathrm{TiO} 3$ ceramic reaches a dielectric constant of 250 and a Curie temperature of $200 \mathrm{~K}$; when densified by microwaves, it can reach a dielectric constant of the order of 1000 and a 
Curie temperature close to 275K [32]. Similarly, ceramics of the KNN system, densified by plasma pulses present an increase of the piezoelectric constant [33]. In the case of YAG densified by plasma pulses, a decrease in the grain size is noticeable in relation to those obtained by the conventional method, in addition, the density of the ceramics increases since with SPS a more homogeneous structure is achieved [34], [35].

On the other hand, and without losing sight of the aforementioned techniques, it is worth highlighting the relevance of the evolution of the kilns in the case of the conventional densification method, since the properties of the materials can be optimized with variations of the conventional method. In the 70's the densification of ceramics by conventional method reached temperatures between 1100 and $1500^{\circ} \mathrm{C}$ including atmosphere control, densifying in periods close to 10 hours [36]; later on and with the advance of technology, tubular kilns can reach temperatures between 2000 and $2500^{\circ} \mathrm{C}$, densifying materials with temperatures close to 1750 for a period of 3 hours [37].

\section{Conventional densification}

Conventional densification is the most used and studied process for obtaining ceramic materials throughout history, the ways to optimize its applications and properties have been of great importance [15];[38];[39];[40], [41] [42][43][3]. This method plays an important role, both in industry and in the laboratory.

The appropriate densification technique for obtaining bricks, roof tiles and handmade ceramics is the conventional method, due to the efficiency in terms of energy in its manufacture. However, in the village of "La codicia", department of Cauca, traditional ceramics are improved by adding other clays in order to achieve greater strength and hardness. According to the study carried out in "La Codicia", the pieces obtained were classified as high plasticity clays. In the Colombian industry, the influence of plasticity and heating rates is also investigated in the conventional densification of tiles and bricks. [44]; [45].

At the research level, the influence of temperatures and densification time of ceramic materials on mechanical, electrical and thermal properties, among others, is studied [41] [46]. The importance of these studies lies in optimizing these properties by varying the densification parameters for a given application and thus being able to improve the ceramics used in the industry [9]. Advanced ceramics must meet very specific property requirements and, therefore, their chemical composition and microstructure must be well controlled. Special attention must be paid to the quality of the starting powders. For advanced ceramics, important powder characteristics are size, size distribution, shape, agglomeration state, chemical composition and phase composition. The surface structure and chemistry are also important [47].

In densification processes there are stages that describe the transformation of ceramic powder particles into grains, the process in which small particles are produced by reducing the size of larger ones by mechanical forces is generally referred to as comminution (operations such as crushing, grinding and milling). The average particle size and particle size distribution of the ground powder depends on a number of factors, including the size, distribution and hardness of the grains formed by them after densification [39]. In general, higher powder quality is associated with higher production cost. Therefore, in each application it should be examined whether the higher production cost is justified by the higher quality of the powder produced [39]; [46].

Other studies explain the densification process from the formation of the neck and the pore, for example, Wang et al, indicate that, the smaller the amount of pores, the higher the strength of the material, in addition, Doni et al, talk about the directly proportional relationship between porosity and elasticity in a material. On the other hand, Yang talks about the advantages and applicability of porous materials, for example, applications such as catalyst supports, high temperature filters, acoustic or thermal insulators, bioreactors, gas sensors, among others [23]; [46]. 


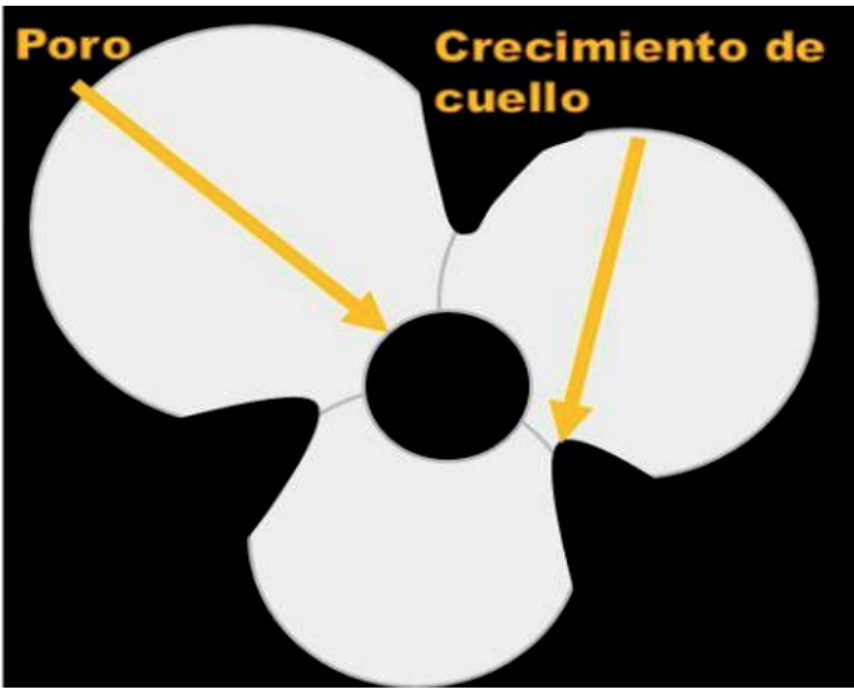

Figure 3. Model of an ideal atomic particle system. Source: Own.

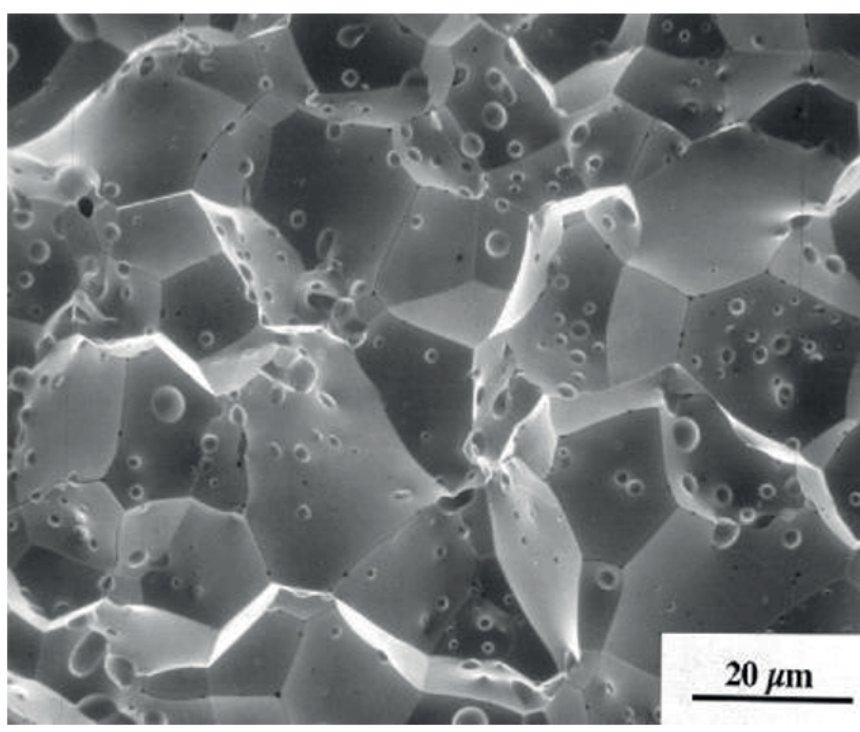

Figure 4. Spherical pores located at grain boundaries, final stage of tungsten. Source: []

During the conventional densification process, neck growth reaches a limit at which diffusion will take over pore shrinkage. The stage change from neck formation to pore shrinkage occurs gradually, and pores appear during the mass transport of neck formation or during grain growth, as shown in Figure 3. Approximating the shape of pores to interconnected tubes, which generally form between grain boundaries, are seen as inherent elements of conventional densification and generally do not bring benefits to the applications one wants to target in ceramic manufacturing [15], however, there are applications for which porosity is important, as in the replacement of bone tissue for which material such as alumina is used, which for application to these tissues it is important that it is $99.5 \%$ pure combined, less than $0.1 \%$, with alkali oxides such as $\mathrm{Na} 2 \mathrm{O}$; porosity plays an important role since it improves mechanical properties, making alumina implants up to $30 \mathrm{GPa}$ hardness [48]. However alumina can, despite its hardness, fracture over time, therefore it is replaced by zirconium oxide which has better chemical and dimensional stability, excellent mechanical strength and fracture toughness, its Young's modulus is close to stainless steel alloys, making it suitable, for example, for femoral head prostheses [48].

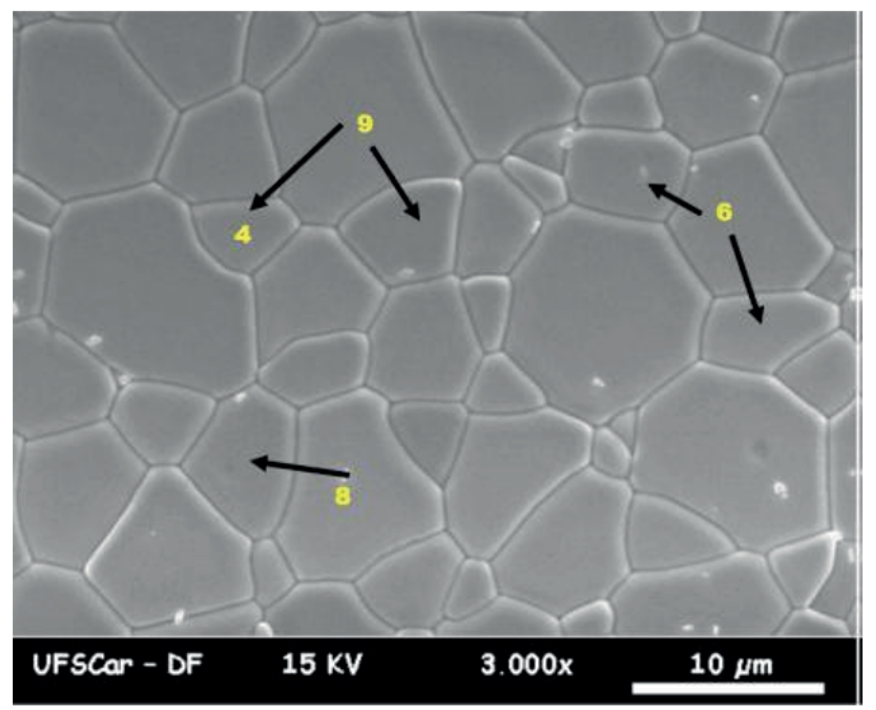

Figure 5 Illustrates how the growth of neighboring neck grains impinge around the pore

Source: [callister].

In general, the shape, size and amount of pores, is information that is observed with Scanning Electron Microscopy micrographs Figure 4; the shape and grain size is usually maintained and the amount of pores tends to decrease [15], this decrease improves the mechanical and optical properties of the ceramics [49]; decreasing the amount of pores or decreasing the pore size can be achieved by controlling the densification atmosphere [50] or by doping the sample [51].

Grain growth occurs as long as it is not kinetically limited. If the formation rate is high, it can promote the isolation of pores within the grain, hindering densification, which is sometimes required, as in the work of Wang where the YbB6 type ceramic prepared with $\mathrm{Yb} 2 \mathrm{O} 3$ and $\mathrm{B} 4 \mathrm{C}$ is analyzed and where porosity values of 58.7, 64.6 and 70.7 percent, with an average pore diameter of $12.58 \mu \mathrm{m}$, are 
found for the manufacture of porous ceramics [46]. On the other hand, when a porous ceramic is not desired, it is solved by means of doping that helps to obtain materials with densities close to their theoretical density and a more homogeneous grain distribution or the use of alternative densification methods such as hot pressing [52], and in the search to inhibit grain growth, methods that apply pressure during densification are chosen. On the other hand, abnormal grain growth, crack formation and pore formation frequently appear in ferroelectric tungstenbronze ceramics prepared by conventional methods, which significantly deteriorate their physical properties [53], [54]. Several strategies have been used to solve such problems, including hot uniaxial pressing, [55], [56] and hot isostatic pressing [55].

As for KNN materials, until recently little was known about these ceramics, and their piezoelectric properties, particularly ceramics such as $\mathrm{NaNbO} 3, \mathrm{KNbO} 3$ and

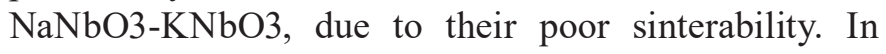
addition, processing control is required to improve the homogeneity of the composition, as high temperatures and long sintering times lead to volatilization of alkali metals. For further densification, temperatures as high as $1200 \mathrm{C}$ are necessary and these temperatures and long residence times lead to abnormal grain growth, especially in $\mathrm{NaNbO} 3$ rich compositions and degradation in the microstructure is observed. Good electrical properties can be found, in the literature, in dense $\mathrm{Na} 0.5 \mathrm{~K} 0.5 \mathrm{NbO} 3$ ceramics prepared by hot pressing methods [28], [57][59].

\section{Densification by hot pressing}

The properties of ceramic materials can be improved by varying the densification parameters, for example by applying pressure and changing the type of heat energy delivered to the system, which implies a change in the residence time of the sample inside the furnace in question, as occurs in hot pressing (HP), where pressure and heat are applied simultaneously, achieving that the ceramics treated by this method achieve compaction and densification in a single step. This method facilitates obtaining stronger, harder, denser ceramics (with porosity close to zero and a complete inter-particle bond) [60], a better microstructure, decreases the densification temperatures and accelerates the densification time with respect to the conventional method [61].
The pressing can be performed in two ways, isostatic (PIC) Figure 7 uniaxial (PUC) Figure 8 [62], [24]. The furnace used in PUC is shown schematically in Figure 7, it consists of a graphite furnace, sheathed with CaF2 and $\mathrm{Pb}$ foil. The $\mathrm{CaF} 2$ layer crumbles at high pressure and acts as a pressure transmitting medium. The $\mathrm{Pb}$ foil acts as a lubricant for the furnace assembly during ejection after the experiment [23]. However, hot pressing presents some technical problems: selection of the mold to withstand the high densification temperatures, long production cycles, and maintenance of atmospheric control [60]. Hot isostatic pressing (HIP) consists of making a perpendicular pressure on all surfaces of the powder, which is in a flexible mold, is usually performed by an argon or helium gas and is given by the ratio between the particle force and the particle contact area, as illustrated in Figure 7. The furnace, Figure 8, consists of a heater that produces high temperature, a thermal barrier that keeps the inside of the furnace at high temperature and a temperature control system; PIC furnaces use a combination of the heat transfer types, conduction, convection and radiation, where the gas has a low conductivity, resulting in the sample not being significantly heated by the gas [24].

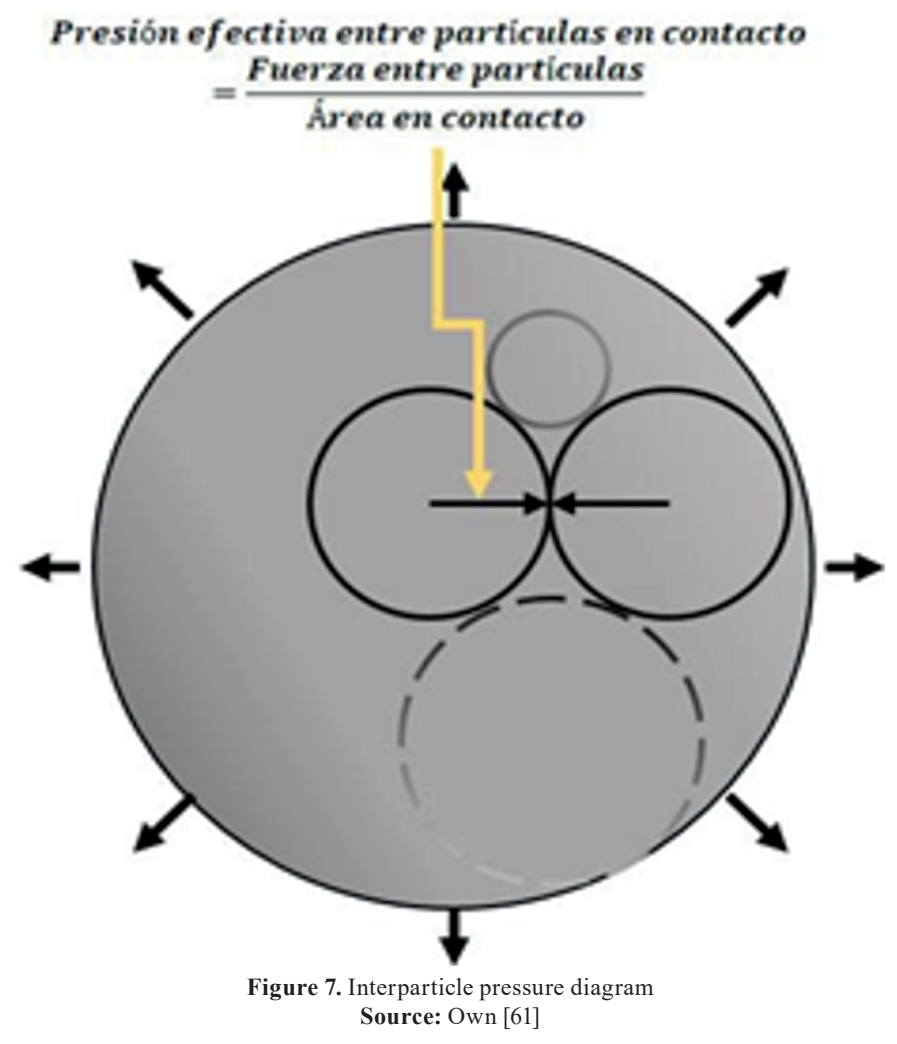




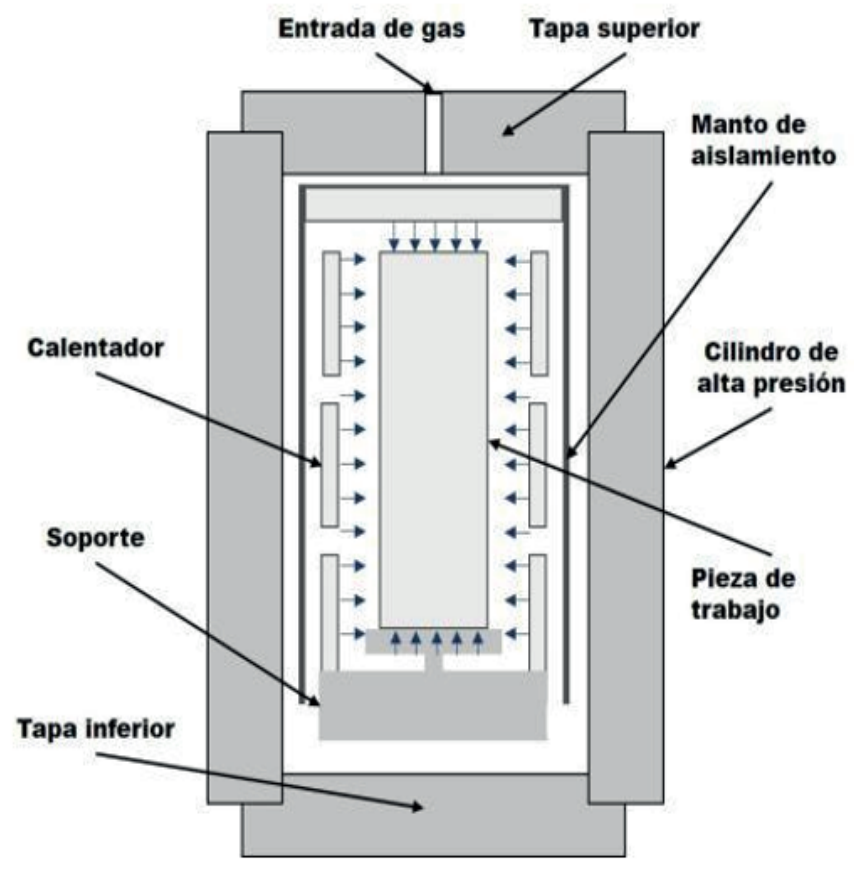

Figure 8. Diagram of the furnace used for the PIC

Source: Own [24]

Powders contained in glass or metal vessels that determine the shape of the sample for hot-press densification allowed finding a model in which grain growth occurs by grain boundary migration where, as in the conventional method, it is mediated by atomic diffusion, interfacial reaction and by the activation energy related to the temperature and residence time of the sample [63].

The relationship between size and length of stay is described by Beck's equation (7)

$D-D_{0}=k_{1} t^{n}$ (6)

Where $\mathrm{D}$ is the average grain size measured in $\mathrm{m}, \mathrm{D} 0$ is the average initial grain size of the sample, $t$ is the residence time, $\mathrm{k} 1$ is the material constant and $\mathrm{n}$ is the grain growth exponent [63], [64]. The coefficients $n$ and $\mathrm{k} 1$ can be calculated, experimentally, by ratifying equation (8)

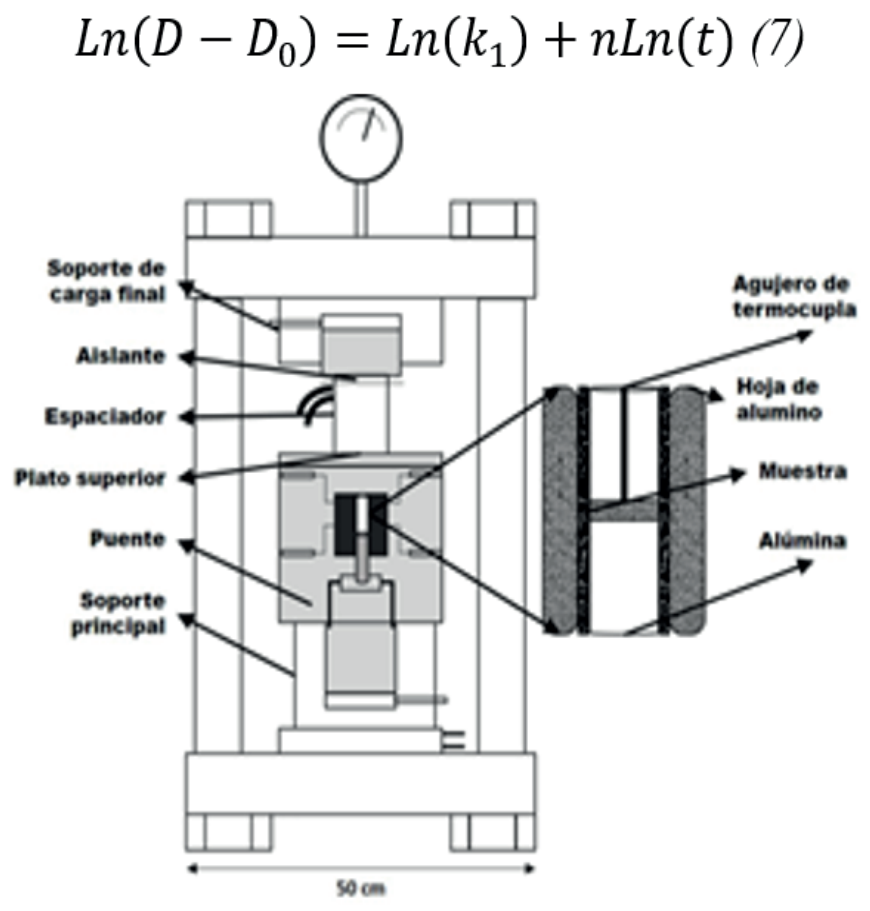

Figure 6. Diagram of the furnace used for heating at PUC Source: [24]

The experimentally calculated values were found to fit the theoretical data adequately. Jia also analyzed the relationship between the average grain size and temperature at a given time and is described by the Hillert equation (9) [63].

$$
D^{2}-D_{0}^{2}=k_{2} t e^{\frac{-Q}{R T}}(8)
$$

Where $\mathrm{Q}$ is the activation energy, $\mathrm{R}$ the gas constant and $\mathrm{T}$ the temperature; the activation energy and the material constant $\mathrm{k} 2$ are obtained from equation (9) [63].

$$
\operatorname{Ln}\left(\frac{D^{2}-D_{0}^{2}}{t}\right)=\operatorname{Ln} k_{2}-\frac{Q}{R T}(9)
$$

Relying on the above model and experimental data taken by Jia, it is observed that the Beck equation and the data coincide temporally [63]. The alloy studied was $\mathrm{Ti} 22 \mathrm{~A} 125 \mathrm{Nb}$, initially treated with $1050^{\circ} \mathrm{C}$ under a pressure of $35 \mathrm{MPa}$ and for $1 \mathrm{~h}$, the structural analysis was performed with temperatures between $1010 \mathrm{C}$ and 1110 C, with residence times of 10, 30 min, 1, 2 and 3 hours. The grain growth, grain boundary reduction and grain 
boundary free energy decreased; the increase in average grain size is more affected by the increase in temperature than by the residence time [63]. The experimental part showed that

$D_{\beta_{2}}^{2}=1,84 \times 10^{7} t e^{\left(\frac{-139276}{R t}\right)}+218^{2} ; D_{\alpha_{2}+\beta_{2}}^{2}=2,625 \times 10^{5} t e^{\left(\frac{-92025}{R t}\right)}+218^{2}$

Using the Hillert equation (9).

However, there are properties that make a material not so efficient and that appear specific to the densification method, for example, in the manufacture of transparent PLZT ceramics, lanthanum-modified lead zirconate titanate improves its optical properties with hot pressing and controlled atmosphere [65], [66].

For other types of ceramics such as KNN, increasingly better results are observed with materials, in particular with NaxK1-xNbO3, the pulsed plasma technique seems to be the more suitable method than hot pressing, to improve mass transport, reducing both temperature and densification time. The study by Wang [67] using the plasma method clearly demonstrated that ceramics with a density close to $98 \%$ can be obtained at temperatures of 1040-1100 for $\mathrm{x}=0.5,0.6$ and 0.7. The authors also characterized plasma sintered ceramics, comparing the results with hot pressed ceramics. They concluded that the plasma pulse sintered NaxK1-xNbO3 samples have higher room temperature dielectric constants, higher coercive fields, lower remanent polarizations and lower electromechanical coefficients. All these results seem to be related to smaller grain sizes or, consequently, larger grain boundary areas. The same system was also studied by Li for $\mathrm{x}$ values ranging from $0 ; 2$ to $0 ; 8$ [2] [68]. They obtained ceramic materials with a high degree of densification when by plasma method was carried out at a temperature as low as $920 \mathrm{C}$.

\section{Plasma pulse densification}

Ceramics generally must meet a number of properties that make it a competent material with the new technologies that are becoming more demanding every day, and the conventional method and hot pressing, although still in force, fail to give the ceramics the characteristics of the new requirements, while the plasma pulse improves the microstructure and makes the material more competent in relation to the materials densified by other methods.
Plasma pulse densification consists of the application of direct current on the sample (conductive or insulating), while external pressure is applied; if the sample is conductive, then it will be heated by the Joule effect and if the sample is insulating it will be heated by induction through a graphite mold, which contains the sample [69]. The parameters that influence the densification of the samples are: current, residence time and pressure. The current has a great effect, since the temperature gradient will depend on its distribution in the sample, which will directly affect the transport mechanisms in the densification. The distribution will depend on the geometry of the mold and the electrical characteristics of the sample and the mold. The way the sample is radiated, with the on:off pattern of current pulses, influences the rate of densification; for conductive samples the final grain size will be affected as the on:off ratio increases as the temperature increases, while for insulating materials the homogeneity of the microstructure may be compromised. Temperature distribution, particularly in insulating samples, can result in density gradient which results in decreased mechanical strength [69], [70]. The plasma pulse method has very short densification cycles, which contributes, so that grain growth is minimized; the effect of residence time can contribute to minimize temperature gradients, but if it is prolonged it also results in grain growth. The pressure contributes to the decrease of the densification temperature helping to eliminate pores and agglomerates, which generates a better distribution of the temperature gradient and a greater homogeneity in the sample avoiding defects [69].En este caso, el horno de densificación consta de una prensa uniaxial, cámara de refrigeración, el generador de corriente eléctrica y un pirómetro para medir la temperatura del sistema y se muestra un esquema básico en la Figura 9, es importante tener en cuenta que el equipo puede trabajar con atmósferas reductoras o inertes mas no con medios oxidantes para evitar el desgaste del molde grafito [69]. 


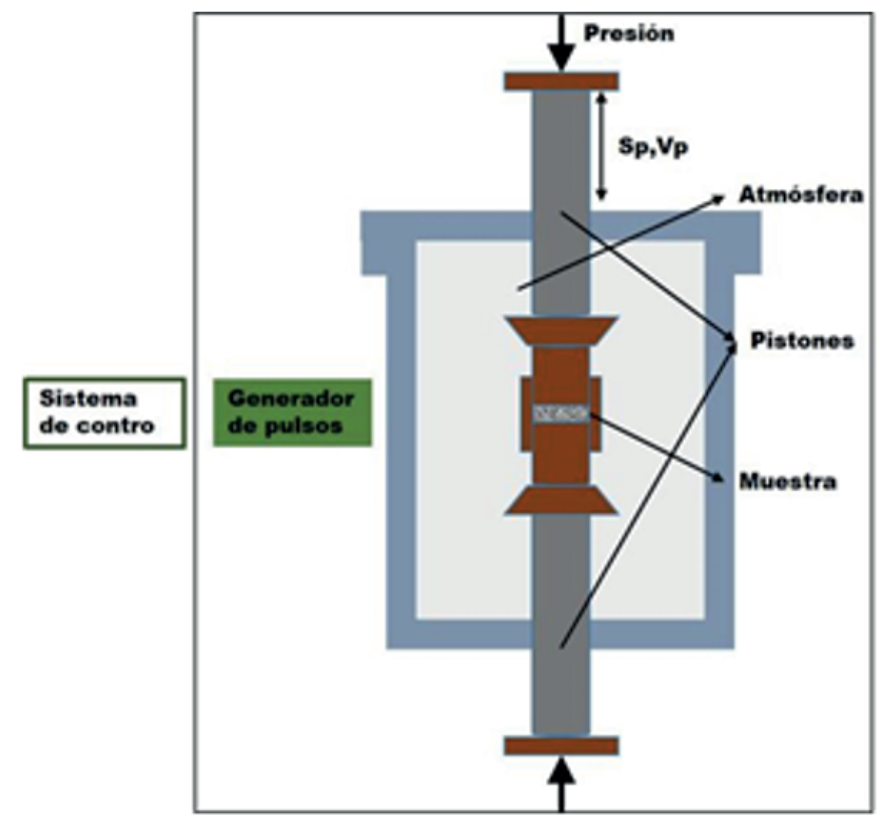

Figure 9. Plasma implosion densification furnace

Source: Own [73]

In polycrystalline and lead-free ceramic materials such as $94 \mathrm{Na} 0.5 \mathrm{Bi} 0.5 \mathrm{TiO} 36 \mathrm{BaTiO} 3$, plasma densification improves the density of the sample even in polycrystalline samples such as this one. Some properties that may show advantages of plasma pulse densification over conventional densification are reflected in results such as the high density achieved by the plasma method of 99.9 $\%$, which translates into a material without pores; while the same material conventionally densified achieves a percentage of density with respect to the theoretical $94 \%$. In addition, the dielectric properties are also improved in plasma densified samples compared to the conventional method. The importance that they are lead-free is because it reduces the negative effects on human health in the manufacturing process [71].

Also, although the activation energy of the direct current, in the plasma method, and the grain contribution, in the conventional method, are similar, it is observed that in materials such as (Li1+x MxTi2x PO4) 3 for the plasma method, the ionic conductivity improves because, if the density increases, as in the case with plasma, the conductivity of the material also increases.

Due to the number of variables involved in the plasma pulse method, few models describing the mass transport have been developed considering only the Joule effect which disregards the direct participation of the current, therefore, considering this direct influence, we will speak of the Olevsky and Froyen model as the closest, so far, in the description of the process of densification by plasma pulses. The approximations of this model, omit factors such as spatial non-uniformity, sources of grain growth, role of surface diffusion, phase transformations, possible (still debatable) plasma formation, presence of surface oxides and considering as main components grain boundary diffusion and power law creep. The driving sources for these material transport mechanisms are: externally applied charge, surface tension and electromigration (electric field contribution to diffusion) [72].

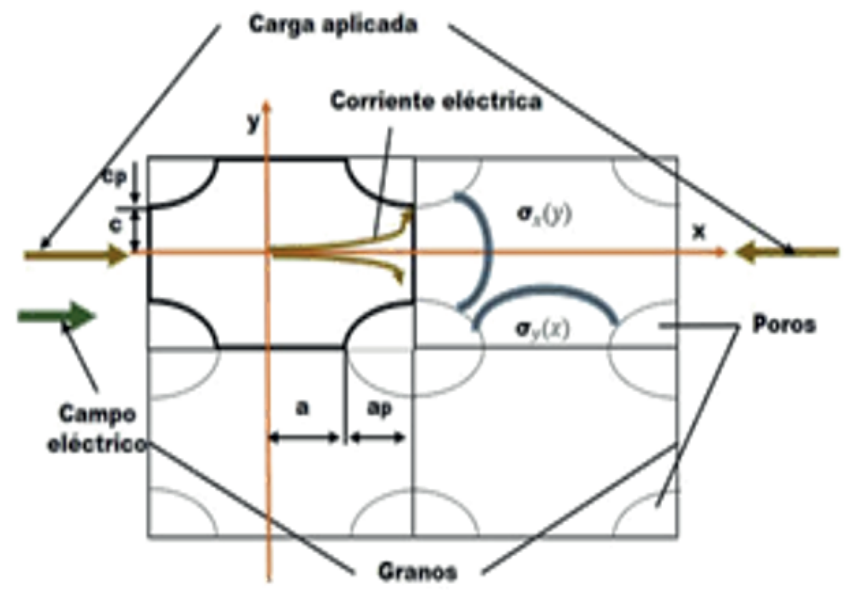

Figure 10. Grain diagram in plasma pulse densification.

Source: Own

The Olevsky and Froyen model is based on the half-axes of rectangular grains and elliptical pores, as shown in Figure 10.

\section{References}

[1] J. Schwartz and G. A. Merritt, "Proof of principle experiments for react wind sinter manufacturing of $\mathrm{Bi} 2 \mathrm{Sr} 2 \mathrm{CaCu} 2 \mathrm{O}$ x magnets," Supercond. Sci. Technol., vol. 20, no. 10, pp. L59-L62, 2007.

[2] B. P. Zhang, J. F. Li, K. Wang, and H. Zhang, "Compositional dependence of piezoelectric properties in $\mathrm{Na} \times \mathrm{K} 1-\mathrm{xNbO} 3$ lead-free ceramics prepared by spark plasma sintering," J. Am. Ceram. Soc., vol. 89, no. 5, pp. 1605-1609, 2006. 
[3] T. N. \& M. N. Yasuyoshi Saito, Hisaaki Takao, Toshihiko Tani, Tatsuhiko Nonoyama, Kazumasa Takatori, Takahiko Homma, "Leadfree piezoceramics," Phys. Status Solidi B, vol. 432, no. November, pp. 1-4, 2004.

[4] G. S. Snow, "Improvements in Atmosphere Sintering of Transparent PLZT Ceramics," J. Am. Ceram. Soc., vol. 56, no. 9, pp. 479-480, 1973.

[5] H. Maiwa, "Dielectric and Electromechanical Properties of (K,Na)NbO 3 Ceramics Prepared by Hot Isostatic Pressing," Ferroelectrics, vol. 491, no. 1, pp. 71-78, 2016.

[6] R. R. Menezesa, P. M. Soutob, and R. H. G. A. Kiminamib, "Microwave fast sintering of submicrometer alumina," Mater. Res., vol. 13, no. 3, pp. 345-350, 2010.

[7] X. Zhu, Piezoelectric ceramics material: processing, properties, charaterization and aplications., no. March. 2017.

[8] A. S. S. De Camargo et al., "Infrared to visible frequency upconversion temperature sensor based on Er3+-doped PLZT transparent ceramics," Solid State Commun., vol. 137, no. 1-2, pp. 1-5, 2006.

[9] A. SUÁREZ, M. Durruthy-Rodríguez, D. MAYOR, A. Aulet, and C. BELLO, INFLUENCIA DEL DOPAJE SIMULTANEO CON La Y Nb EN LA SINTERIZACION DE CERAMICAS PIEZOELECTRICAS PZT 54/46, vol. 19, no. January. 2002.

[10] K. Uchino, Future of Ferroelectric Devices, 2nd ed. 2009.

[11] S. COHEN, "Novel VOAs provide more speed and utility," Laser Focus world, vol. 36, no. 11, pp. 139-146, 2000.
[12] S. Cohen and P. Melman, "New breakthrough design for VOAs based on electro-optic materials."

[13] H. Jiang et al., "Transparent electro-optic ceramics and devices," Proc. SPIE, vol. 5644, no. 1, p. 380, 2005.

[14] J. Y. Cheng and Q. Chen, "An ultrafast phase modulator for 3D imaging," Sensors, Cameras, Syst. Sci. Appl. VII, vol. 6068, p. 60680L, 2006.

[15] R. German, Sintering: From Empirical Observations to Scientific Principles. 2014.

[16] C. Huerta, M. Vilafranca, and P. U. Jaume, "CERÁMICA: ORIGEN, EVOLUCIÓN Y TÉCNICAS,” 2007.

[17] C. Huerta, M. Vilafranca, and P. U. Jaume, Cerámica: origen, evolución y técnicas., 1 st ed. Castellon de la plana, 2007.

[18] Y. Gong, Z.-G. Liu, Y.-J. Jin, J.-H. Ouyang, L. Chen, and Y.-J. Wang, "Effect of sintering process on the microstructure and ionic conductivity of Li7-xLa3Zr2-xTaxO12 ceramics," Ceram. Int., vol. 45, no. 15, pp. 18439-18444, Oct. 2019.

[19] L. Ouyang, W. Wang, H. Fan, Z. Weng, W. Wang, and H. Xue, "Sintering behavior and microwave performance of $\mathrm{CaSiO} 3$ ceramics doped with $\mathrm{BaCu}(\mathrm{B} 2 \mathrm{O5})$ for LTCC applications," Ceram. Int., vol. 45, no. 15, pp. 18937-18942, Oct. 2019.

[20] H.-M. Kim, Y.-W. Kim, and K.-Y. Lim, "Pressureless sintered silicon carbide matrix with a new quaternary additive for fully ceramic microencapsulated fuels," J. Eur. Ceram. Soc., vol. 39, no. 14, pp. 3971-3980, Nov. 2019.

[21] E. de A. Francisco Alcántara, "Cerámica." [Online]. Available: http://ceramica.name/ tecnologia_ceramica/ceramica/Ceramica.html. 
[Accessed: 11-Mar-2018].

[22] N. Shanbhog, V. K., A. N., and S. R. Bakshi, "Effect of graphene nano-platelet addition on the microstructure and spark plasma sintering kinetics of zirconium diboride," Int. J. Refract. Met. Hard Mater., vol. 84, p. 104979, Nov. 2019.

[23] S. F. Wang et al., "Transparent ceramics: Processing, materials and applications," Prog. Solid State Chem., vol. 41, no. 1-2, pp. 20-54, 2013.

[24] M. H. Bocanegra-Bernal, "Hot isostatic pressing (HIP) technology and its applications to metals and ceramics," J. Mater. Sci., vol. 39, no. 21, pp. 6399-6420, 2004.

[25] S.-F. Liu, I. R. Abothu, and S. Komarneni, "PLZT ceramics prepared from conventional and microwave hydrothermal powders," Mater. Lett., vol. 38, no. October 2014, pp. 344-350, 1999.

[26] G. H. Haertling, "Ferroelectric ceramics: History and technology," J. Am. Ceram. Soc., vol. 82, no. 4, pp. 797-818, 1999.

[27] L. A. Celi, A. C. Caballero, M. Villegas, P. Durán, C. Moure, and J. F. Fernández, "Cerámica y Vidrio Microestructura y propiedades de materiales cerámicos PZT con control de crecimiento de grano," vol. 491, pp. 487-491, 1999.

[28] B. Malič et al., "Sintering of lead-free piezoelectric sodium potassium niobate ceramics," Materials (Basel)., vol. 8, no. 12, pp. 8117-8146, 2015.

[29] G. S. Snow, "Fabrication of Transparent Electrooptic PLZT Ceramics by Atmosphere Sintering," J. Am. Ceram. Soc., vol. 56, no. 2, pp. 91-96, 1973.

[30] F. A. Londoño, J. A. Eiras, and D. Garcia,
"Optical and electro-optical properties of $(\mathrm{Pb}, \mathrm{La})$ TiO3 transparent ceramics," Opt. Mater. (Amst)., vol. 34, no. 8, pp. 1310-1313, 2012.

[31] D. Garcia, "Síntese e caracterizacao de ceramicas ferroelectricas transparentes do sistema $(\mathrm{Pb}, \mathrm{La})$ (Zr,Ti)O3," universidade de Sao Paulo, 1995.

[32] K. R. Carroll, J. M. Pond, D. B. Chrisey, J. S. Horwitz, R. E. Leuchtner, and K. S. Grabowski, "Microwave measurement of the dielectric constant of $\mathrm{Sr} 0.5 \mathrm{Ba} 0.5 \mathrm{TiO} 3$ ferroelectric thin films," Appl. Phys. Lett., vol. 62, no. 15, pp. 1845-1847, 1993.

[33] Y. Zhen, J. F. Li, K. Wang, Y. Yan, and L. Yu, "Spark plasma sintering of Li/Ta-modified (K,Na)NbO 3 lead-free piezoelectric ceramics: Post-annealing temperature effect on phase structure, electrical properties and grain growth behavior," Mater. Sci. Eng. B Solid-State Mater. Adv. Technol., vol. 176, no. 14, pp. 1110-1114, 2011.

[34] R. Chaim, M. Kalina, and J.Z. Shen, "Transparent yttrium aluminum garnet (YAG) ceramics by spark plasma sintering," J. Eur. Ceram. Soc., vol. 27, no. 11, pp. 3331-3337, 2007.

[35] L. Wen, X. Sun, Z. Xiu, S. Chen, and C. T. Tsai, "Synthesis of nanocrystalline yttria powder and fabrication of transparent YAG ceramics," J. Eur. Ceram. Soc., vol. 24, no. 9, pp. 2681-2688, 2004.

[36] M. Hoch and K. M. Nair, "Densification characteristics of ultrafine powders," Ceramurg. Int., vol. 2, no. 2, pp. 88-97, 1976.

[37] X. F. Wang, H. M. Xiang, X. Sun, J. C. Liu, F. Hou, and Y. C. Zhou, "Porous YbB6 Ceramics Prepared by in Situ Reaction between Yb2O3 and B4C Combined with Partial Sintering," $J$. Am. Ceram. Soc., vol. 98, no. 7, pp. 2234-2239, 2015. 
[38] V. G. Lee and T. H. Yeh, "Sintering effects on the development of mechanical properties of fired clay ceramics," Mater. Sci. Eng. A, vol. 485, no. 1-2, pp. 5-13, 2008.

[39] X. Kuang, G. Carotenuto, and L. Nicolais, “A review of ceramic sintering and suggestions on reducing sintering temperatures," Adv. Perform. Mater., vol. 4, no. 3, pp. 257-274, 1997.

[40] C. Baudin and J. S. Moya, "Sinterizacion en estado solido," Boletín la Soc. Española Ceram. y Vidr., vol. 22, pp. 133-142, 1983.

[41] A. Herabut and A. Safari, "Processing and Electromechanical Properties of (Bi0.5Na0.5) (1-1.5x)LaxTiO3 ceramics," J. Am. Ceram. Soc., vol. 80, pp. 2954-2958, 1997.

[42] A. Ikesue and Y. L. Aung, "Ceramic laser materials," Nat. Photonics, vol. 2, no. 12, pp. 721-727, 2008.

[43] J. Schwartz and G. A. Merritt, "Proof-ofprinciple experiments for react-wind-sinter manufacturing of Bi $2 \mathrm{Sr} 2 \mathrm{CaCu} 2 \mathrm{O}$ x magnets," Supercond. Sci. Technol., vol. 20, no. 10, pp. L59-L62, 2007.

[44] J. D. S. AMADO, P. Y. M. VILLAFRADES, and E. M. C. TUTA, "Caracterización De Arcillas Y Preparación De Pastas Cerámicas Para La Fabricación De Tejas Y Ladrillos En La Región De Barichara, Santander," Dyna, vol. 78, no. 167 , pp. 50-58, 2011.

[45] J. A. Muñoz Chaves, R. A. Muñoz Menese, P. Mancill, and J. E. Rodríguez Páez, "Estudio del procesamiento cerámico de las arcillas de la vereda ' La Codicia' ( Guapi , Colombia ) para potencializar su uso en la elaboración de piezas cerámicas," Fac. Ing. Univ. Antioquia., vol. 42, pp. 68-78, 2007.
[46] X.-F. Wang, H.-M. Xiang, X. Sun, J.-C. Liu, F. Hou, and Y.-C. Zhou, "Porous YbB 6 Ceramics Prepared by In Situ Reaction between Yb 2 O 3 and B 4 C Combined with Partial Sintering," J. Am. Ceram. Soc., vol. 2239, no. 36123, p. n/an/a, 2015.

[47] A. Piras et al., "Structural and morphological investigation of ceria-promoted $\mathrm{Al} 2 \mathrm{O} 3$ under severe reducing/oxidizing conditions," J. Phys. Chem. B, vol. 109, no. 22, pp. 11110-11118, 2005.

[48] F. J. DELGADO GARCÍA, MENOCAL, J.A., MOREJÓN, L., MARTÍNEZ, S., GIL, "Cerámicas de circona para aplicaciones biomédicas," BIomecanica, vol. 11, pp. 46-52, 2003.

[49] A. SUÁREZ, M. Durruthy-Rodríguez, D. MAYOR, A. Aulet, and C. BELLO, INFLUENCIA DEL DOPAJE SIMULTANEO CON La Y Nb EN LA SINTERIZACION DE CERAMICAS PIEZOELECTRICAS PZT 54/46, vol. 19. 2002.

[50] E. Bash, “Cerámicas: cocción,” PhD Propos., vol. 1, pp. 1-26, 2015.

[51] E. Giraldo Tobón and P. Abad Mejía, “Obtención de precursores con tamaño de artícula nano y micrométrico para la fabricación de materiales cerámicos con propiedades eléctricas no lineales. (Spanish)," OBTAINING PRECURSORS WITH NANO MICROMETRIC Part. SIZE Synth. Ceram. Mater. WITH NONLINEAR Electr. Prop., pp. E15-E23, 2014.

[52] M. Suárez, Matriales Cerámicos Policristalinos Al2O3 y YAG Con funcionalidad Óptica. 2009.

[53] H. Lee, R. Freer, H. Lee, and R. Freer, "The mechanism of abnormal grain growth in $\mathrm{Sr} 0$. 6Ba0 . 4Nb2O6 ceramics," vol. 376, no. 1997, 
2012.

[54] T. Hiroshima, K. Tanaka, and T. Kimura, "Effects of microstructure and composition on the curie temperature of lead barium niobate solid solutions." p. 79, 1996.

[55] T. Takeuchi, M. Tabuchi, I. Kondoh, N. Tamari, and H. Kageyama, "Synthesis of Dense Lead Titanate Ceramics with Submicrometer Grains by Spark Plasma Sintering," J. Am. Ceram. Soc., vol. 83, no. 3, pp. 541-544, 2000.

[56] G. Zhang et al., "Large enhancement of the electrocaloric effect in PLZT ceramics prepared by hot-pressing," APL Mater., vol. 4, no. 6, 2016.

[57] R. E. JAEGER and L. EGERTON, "Hot Pressing of Potassium-Sodium Niobates," J. Am. Ceram. Soc., vol. 45, no. 5, pp. 209-213, 1962.

[58] H. F. Alkali and N. Ceramics, "Properties of HotPressed Ferroelectric Alkali Niobate Ceramics," no. June, pp. 329-330, 1967.

[59] J. F. Li, K. Wang, F. Y. Zhu, L. Q. Cheng, and F. Z. Yao, “(K, Na) NbO3-based lead-free piezoceramics: Fundamental aspects, processing technologies, and remaining challenges," J. Am. Ceram. Soc., vol. 96, no. 12, pp. 3677-3696, 2013.

[60] M. P. Groover, Fundamentos de manufactura moderna, 3rd ed. México, 2007.

[61] H. T. Larker, Hot Isostatic Pressing of Ceramics - an Overview. Elsevier Science B.V., 1994.

[62] B. Nayebi, M. Shahedi Asl, M. Ghassemi Kakroudi, and M. Shokouhimehr, "Temperature dependence of microstructure evolution during hot pressing of $\mathrm{ZrB} 2-30 \mathrm{vol} . \% \mathrm{SiC}$ composites," Int. J. Refract. Met. Hard Mater., vol. 54, pp. 7-13, 2016.
[63] J. Jia et al., "B2 Grain Growth Behavior of a Ti-22Al-25Nb Alloy Fabricated by Hot Pressing Sintering," J. Mater. Eng. Perform., 2018.

[64] J. E. Burke and D. Turnbull, "Recrystallization and grain growth," Prog. Met. Phys., vol. 3, pp. 220-292, 1952.

[65] G. S. SNOW, "Fabrication of Transparent Electrooptic PLZT Ceramics by Atmosphere Sintering," J. Am. Ceram. Soc., vol. 56, no. 2, pp. 91-96, 1973.

[66] Y. Abe, K. Kakegawa, H. Ushijima, Y. Watanabe, and Y. Sasaki, "Fabrication of Optically Transparent Lead Lanthanum Zirconate Titanate $((\mathrm{Pb}, \mathrm{La})(\mathrm{Zr}, \mathrm{Ti}) \mathrm{O} 3)$ Ceramics by a Three-StageAtmosphere-Sintering Technique," J. Am. Ceram. Soc., vol. 85, no. 2, pp. 473-475, 2004.

[67] R. Wang, R. Xie, T. Sekiya, and Y. Shimojo, "Fabrication and characterization of potassium sodium niobate piezoelectric ceramics by sparkplasma-sintering method," vol. 39, pp. 17091715, 2004.

[68] Jing-Feng Li *, "Ferroelectric and piezoelectric properties of fine-grained na $05 \mathrm{k} 05 \mathrm{nbo} 3$ lead free piezoelectric ceramics prepared by spark plasma sintering," vol. 709, pp. 706-709, 2006.

[69] Á. C. Isabel, "COMPOSITES MULTIFUNCIONALES DE ALÚMINA SINTERIZADOS POR SPARK PLASMA SINTERING," 2012.

[70] Z. Shen, M. Johnsson, Z. Zhao, and M. Nygren, "Spark Plasma Sintering of Alumina," J. Am. Ceram. Soc., vol. 85, no. 8, pp. 1921-1927, 2002.

[71] M. Gurbuz, O. May, and A. Do, "Sintering of $94 \mathrm{Na} 0.5 \mathrm{Bi} 0.5 \mathrm{TiO} 3-6 \mathrm{BaTiO} 3$ with SPS and conventional methods for crystal growth," no. March, pp. 1-6, 2016. 
[72] E. Olevsky and L. Froyen, "Constitutive modeling of spark-plasma sintering of conductive materials," Scr. Mater., vol. 55, no. 12, pp. 11751178, 2006.

[73] Á. C. Isabel, "Composites multifuncionales de alúmina sinterizados por spark plasma sintering," 2012. 